Journal of Elemantary School (JOES)

Volume 1, Nomor 2, Desember 2018

e-ISSN : 2615-1448

p-ISSN : 2620-7338

DOI : https://doi.org/10.31539/joes.v1i2.474

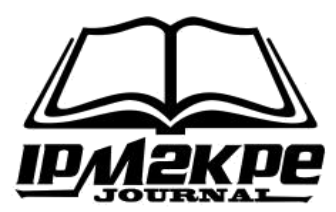

\title{
PENERAPAN MODEL PEMBELAJARAN THINK TALK WRITE DALAM MENINGKATKAN HASIL BELAJAR
}

\author{
Siti Marliana \\ SDN 49 Lubuklinggau \\ sitimarlina2018@gmail.com
}

\begin{abstract}
ABSTRAK
Tujuan dalam penelitian ini adalah mengetahui peningkatan penerapan model pembelajaran Think Talk Write terhadap siswa kelas VI SD Negeri 49 Lubuklinggau pada materi zakat. Penelitian ini menggunakan pendekatan penelitian tindakan kelas (PTK). Hasil penelitian, keadaan sebelum perbaikan pembelajaran, jumlah siswa yang mencapai ketuntasan belajar atau memperoleh nilai $\geq 70$ baru mencapai 10 orang $(29.41 \%)$, pada siklus I yang mencapai ketuntasan belajar 23 orang $(67.61 \%)$ dan pada siklus II tingkat ketuntasan mencapai 31 orang (91.18\%), maka penerapan model pembelajaran dalam meningkatkan hasil belajar siswa berhasil, karena sudah memenuhi syarat ketuntasan minimal klasikal yaitu $85 \%$ siswa yang mencapai nilai $\geq 70$. Simpulan, penerapan model pembelajaran think talk write dapat meningkatkan hasil belajar siswa.
\end{abstract}

Kata Kunci : Model Pembelajaran, Think Talk Write, Hasil Belajar

\section{ABSTRACT}

The study aims to find out the application of Think Talk Write method to thebsixth grade students at SD Negeri 49 Lubuklinggau in the material of 'islamic tithe'. This study was a classroom action research (CAR). The result showed, before treatment, the students score were passed or $\geq 70$ reached by 10 students $(29.41 \%)$. in cycle I, there were 23 students who passed the passing grade (67.61\%) and in cycle II there were 31 students who passed (91.18\%). Therefore, the method improved students achievement because $85 \%$ students passed the passing grade with score $\geq 70$. Finally, the application of think talk write can improve students achievement.

Keywords: Teaching Method, Think Talk Write, Achievement 


\section{PENDAHULUAN}

Dalam pembukaan Undang-Undang Dasar 1945 tercantum bahwa tujuan pendidikan nasional adalah mencerdaskan kehidupan bangsa. Di samping itu juga, dalam Undang-undang Nomor. 20 tahun 2003 Pasal 3 tentang Sistem Pendidikan Nasional telah dijelaskan bahwa pendidikan nasional bertujuan untuk mengembangkan potensi peserta didik agar menjadi manusia yang beriman dan bertakwa kepada Tuhan Yang Maha Esa, berakhlak mulia, sehat, berilmu, cakap, kreatif, mandiri dan menjadi warga negara yang bertanggung jawab. Maka dalam hal ini pemerintah mengadakan pembangunan sumber daya manusia melalui pemerataan pendidikan dengan menugaskan pendidik (guru) sebagai abdi negara untuk menciptakan dan membentuk manusia Indonesia sebagai peserta didik yang kritis dan berpotensi.

Pendidikan diarahkan kepada pembentukan manusia yang diidamkan dan bertujuan untuk meningkatkan kualitas manusia Indonesia yaitu manusia yang beriman dan bertaqwa kepada Tuhan Yang Maha Esa, berbudi pekerti luhur, berkepribadian, berdisiplin, bekerja keras, tangguh, dan bertanggung jawab, mandiri, cerdas, terampil, serta sehat jasmani dan rohani.

Pendidikan adalah proses interaksi pendidik dan peserta didik yang memiliki tujuan tertentu (Nadir, 2009). Dalam kehidupan berbangsa, pendidikan mempunyai peranan yang sangat penting untuk menjamin pembentukan sumber daya manusia yang berkualitas. Dimana pendidikan merupakan suatu kegiatan yang kompleks, banyak variabel yang mempengaruhinya. Pendidikan tidak dapat dipisahkan dari kegiatan belajar mengajar itu antara lain guru/pendidik ataupun pihak yang mendidik juga siswa yang melakukan aktivitas belajar (Anita, 2008)).

Penerapan kurikulum Tingkat Satuan Pelajaran (KTSP) pada sekolah kurikulum berbasis kompetensi, seseorang guru dituntut kreativitas untuk bisa mengembangkan pembelajaran, guru harus mampu mengatasi dan mengantisipasi gejala yang muncul dalam proses belajar mengajar di sekolah agar hasil belajar siswa dapat optimal. Salah satu mata pelajaran yang dianggap atau diasumsikan banyak menghadapi kendala dan hambatan dalam pembelajaran adalah pelajaran PAI. Bahkan, pelajaran PAI dianggap Sulit karena harus menghafal sejarah-sejarah dan perkembangan dunia bagi peserta didik (Sapriya, 2008).

Pembelajaran PAI yang baik tentunya tidak akan membuat siswa mengalami kesulitan dalam mengikuti proses pembelajaran mata pelajaran itu sendiri. Guru sebagai fasilitator dalam proses pembelajaran tentunya dapat meminimalisir kondisi tersebut dengan menggunakan bahkan memvariasikan komponen pembelajaran yang ada. Adanya penggunaan komponen pembelajaran seperti model pembelajaran, metode pengajaran dan media pengajaran akan membantu kesulitan anak dalam belajar PAI (Maidar, 2010) 
Guru sebagai penanggung jawab kegiatan pembelajaran diharapkan mampu merubah anggapan siswa terhadap pelajaran PAI tersebut. Apabila di tingkat sekolah dasar siswa sudah merasa disegani terhadap pelajaran PAI, dapat dipastikan siswa akan mengalami kesulitan pada jenjang pendidikan yang lebih tinggi. Untuk itu guru dapat mengunakan salah satu komponen pembelajaran yaitu melalui penggunaan media pengajaran yang menarik.

Untuk mengetahui tercapai tidaknya tujuan pembelajaran yang diharapkan, maka harus dilakukan penilaian terhadap proses hasil belajar siswa. Pelaksanaan penilaian tersebut dapat dilakukan melalui observasi dan tes ulangan. Penilaian di SD Negeri 49 Lubuklinggau khususnya di Kelas VI pembelajaran dikatakan berhasil jika $80 \%$ dari jumlah siswa telah mencapai nilai KKM (70). Dengan kata lain pembelajaran yang berhasil adalah apabila $80 \%$ siswa dapat menguasai minimal $70 \%$ materi pelajaran, hal ini disebut juga ketuntasan belajar secara klasikal.

Berdasarkan pengamatan penulis selama mengajar di Kelas VI SD Negeri 49 Lubuklinggau, prestasi belajar PAI masih sangat rendah. Hal ini didukung oleh data yang menunjukkan bahwa nilai pelajaran PAI yang belum mencapai ketuntasan. Kurangnya kemampuan tersebut, khususnya pada materi zakat, tercermin dari rendahnya hasil yang diperoleh siswa ketika ulangan harian. Dari 34 siswa yang mencapai ketuntasan belajar sebanyak 10 orang sedangkan yang belum mencapai ketuntasan belajar sebanyak 24 orang dengan rata-rata nilai 61,18. Rendahnya nilai ulangan tersebut disebabkan oleh kurangnya pengalaman belajar mengidentifikasi informasi penting tentang aktivitas ekonomi yang berkaitan dengan sumber daya alam dan potensi lain di daerahnya dengan rasa ingin tahu. Selain itu penyebabnya dari faktor anak juga tidak terlepas dari faktor guru yang mengajar.

Berdasarkan beberapa kekurangan dalam proses pembelajaran yang dilaksanakan, dan hasil diskusi dengan Supervisor 2 maka ada beberapa kekurangan yang menyebabkan rendahnya penguasaan siswa Kelas VI SD Negeri 49 Lubuklinggau Semester Genap tahun pelajaran 2017/2018 dengan materi zakat antara lain guru kurang memotivasi siswa sehingga minat belajar siswa kurang, ditambah lagi guru tidak memperhatikan kemampuan siswa sehingga siswa menjadi sangat pasif.

\section{METODE PENELITIAN}

Penelitian ini merupakan penelitian tidakan (action research), karena penelitian dilakukan untuk memecahkan masalah pembelajaran di kelas. Penelitian ini juga termasuk penelitian deskriftif, sebab menggambarkan bagaimana suatu teknik pembelajaran diterapkan dan bagaimana hasil yang diinginkan dapat dicapai. Perbaikan pembelajaran dilakukan melalui penelitian tindakan kelas (PTK) yang terdiri atas dua siklus. Setiap siklus kegiatan yang dilakukan meliputi : (a). 
Perencanaan; (b). Pelaksanaan;(c). Observasi / pengamatan; dan (d). Refleksi (Wardhani, 2007).

\section{HASIL PENELITIAN}

\section{Deskripsi Hasil Penelitian Perbaikan Pembelajaran}

Prasiklus dilaksanakan pada Rabu, 4 april 2018. Prasiklus dilakukan untuk melihat keaktifan dan hasil belajar siswa. Hasil analisis tes prasiklus (sebelum tindakan perbaikan) dapat dilihat pada tabel berikut:

Tabel 1

Daft ar Nilai Prasiklus Siswa

\begin{tabular}{|c|c|c|c|c|}
\hline \multirow{2}{*}{ No } & \multirow{2}{*}{ Nama Siswa } & \multirow{2}{*}{ Prasiklus } & \multicolumn{2}{|c|}{ Keterangan } \\
\hline & & & Tuntas & Belum Tuntas \\
\hline 1 & Abdullah & 60 & & $\overline{\mathrm{O}}$ \\
\hline 2 & Anis & 45 & & Oे \\
\hline 3 & Agung & 55 & & Ö \\
\hline 4 & Ahmad & 60 & & Ö \\
\hline 5 & Ahyar & 75 & Ö & \\
\hline 6 & $\mathrm{Aji}$ & 70 & $\mathrm{O}$ & \\
\hline 7 & Amelia & 75 & Ö & \\
\hline 8 & Ani & 60 & & Ö \\
\hline 9 & Annisa & 45 & & Ö \\
\hline 10 & Azil & 55 & & Ö \\
\hline 11 & Chelsea & 65 & & Ö \\
\hline 12 & Dhe & 55 & & Ö \\
\hline 13 & Diva & 70 & Ö & \\
\hline 14 & Duta & 70 & Ö & \\
\hline 15 & Endi & 65 & & Ö \\
\hline 16 & Eva & 70 & Ö & \\
\hline 17 & Fahsa & 75 & Oे & \\
\hline 18 & Febrian & 70 & Oे & \\
\hline 19 & Hadi & 65 & & Ö \\
\hline 20 & Hanif & 60 & & Oे \\
\hline 21 & Iqbal & 45 & & O \\
\hline 22 & Ira & 45 & & Ö \\
\hline 23 & Kiki & 55 & & Oे \\
\hline 24 & Lilis & 60 & & O \\
\hline 25 & Lela & 55 & & Ö \\
\hline 26 & Meiza & 60 & & Oे \\
\hline 27 & Meta & 65 & & Oे \\
\hline 28 & Milfi & 65 & & Ö \\
\hline 29 & Tatia & 70 & Oे & \\
\hline 30 & Taza & 70 & Oे & \\
\hline 31 & Tedi & 65 & & Ö \\
\hline 32 & Vero & 55 & & Oे \\
\hline 33 & Yoga & 45 & & Oे \\
\hline 34 & Pebri & 60 & & Ö \\
\hline
\end{tabular}




\begin{tabular}{llll}
\hline Jumlah & 2080 & 10 & 24 \\
\hline Rata-rata & 61.18 & & \\
\hline \% ketuntasan $\geq 70$ & & $29.41 \%$ & $70.59 \%$ \\
\hline \multirow{2}{*}{ Nilai } & Tertinggi & 75 & \\
\cline { 2 - 4 } & Terendah & 40 & \\
\hline
\end{tabular}

Dari tabel 1 di atas hasil prasiklus jumlah anak yang tuntas sebanyak 10 siswa atau sebesar $29,41 \%$ sedangkan yang belum tuntas sebanyak 24 siswa atau 70,59\%. Nilai rata-rata yang diperoleh siswa sebesar 61,18 dengan nilai tertinggi sebesar 75 dan nilai terendah sebesar 40. Jika dilihat dari ketuntasan belajar, terlihat bahwa pada saat pra siklus ini masih belum tuntas. Hal ini dikarenakan ketuntasan siswa hanya sebesar 23,53\%. Sedangkan ketuntasan siswa secara klasikal harus sebesar 85\%. Oleh karena itu diperlukan tindakan selanjutny yaitu pelaksanaan siklus I yang dilaksanakan pada hari Rabu, 11 April 2018.

Tabel 2

Daftar Nilai Siklus I Siswa

\begin{tabular}{|c|c|c|c|c|}
\hline \multirow{2}{*}{ No } & \multirow{2}{*}{ Nama Siswa } & \multirow{2}{*}{ Siklus I } & \multicolumn{2}{|c|}{ Keterangan } \\
\hline & & & Tuntas & Belum Tuntas \\
\hline 1 & Abdullah & 70 & "̈̈ & \\
\hline 2 & Anis & 60 & & Ö \\
\hline 3 & Agung & 60 & & Ö \\
\hline 4 & Ahmad & 75 & Ö & \\
\hline 5 & Ahyar & 80 & Ö & \\
\hline 6 & Aji & 75 & Ö & \\
\hline 7 & Amelia & 80 & Ö & \\
\hline 8 & Ani & 75 & Ö & \\
\hline 9 & Annisa & 75 & Ó & \\
\hline 10 & Azil & 65 & & Ö \\
\hline 11 & Chelsea & 60 & & Ö \\
\hline 12 & Dhe & 75 & Oे & \\
\hline 13 & Diva & 70 & Ö & \\
\hline 14 & Duta & 70 & Ö & \\
\hline 15 & Endi & 65 & & Ó \\
\hline 16 & Eva & 75 & Ö & \\
\hline 17 & Fahsa & 70 & Ö & \\
\hline 18 & Febrian & 80 & Oे & \\
\hline 19 & Hadi & 80 & Oे & \\
\hline 20 & Hanif & 75 & Ö & \\
\hline 21 & Iqbal & 70 & Ö & \\
\hline 22 & Ira & 70 & Oे & \\
\hline 23 & Kiki & 65 & & Ó \\
\hline 24 & Lilis & 65 & & Ö \\
\hline 25 & Lela & 70 & Ô & \\
\hline 26 & Meiza & 75 & Ô & \\
\hline 27 & Meta & 65 & & Ö \\
\hline
\end{tabular}




\begin{tabular}{|c|c|c|c|c|}
\hline 28 & Milfi & 65 & & Ō \\
\hline 29 & Tatia & 65 & & Ö \\
\hline 30 & Taza & 70 & Ö & \\
\hline 31 & Tedi & 75 & Ö & \\
\hline 32 & Vero & 75 & Ö & \\
\hline 33 & Yoga & 75 & Ö & \\
\hline 34 & Pebri & 80 & Ö & \\
\hline & & 2420 & 23 & 11 \\
\hline & & 71.18 & & \\
\hline & ntasan $\geq 70$ & & 67.65 & 32.35 \\
\hline \multirow{2}{*}{\multicolumn{2}{|c|}{ Nilai }} & Tertinggi & 80 & \\
\hline & & Terendah & 60 & \\
\hline
\end{tabular}

Dari tabel 2 di atas diperoleh data bahwa jumlah anak yang tuntas sebanyak 23 siswa atau sebesar $67,65 \%$ sedangkan yang belum tuntas sebanyak 11 siswa atau $32,35 \%$. Nilai rata-rata yang diperoleh siswa sebesar 71,18 dengan nilai tertinggi sebesar 80 dan nilai terendah sebesar 60. Jika dilihat dari ketuntasan belajar, terlihat bahwa pada saat siklus I ini masih belum tuntas. Hal ini dikarenakan ketuntasan siswa hanya sebesar $67,65 \%$. Sedangkan ketuntasan siswa secara klasikal harus sebesar $85 \%$. Oleh karena itu diperlukan tindakan selanjutny yaitu pelaksanaan siklus I yang dilaksanakan pada hari Rabu, 18 April 2018.

Tabel 3

Daftar nilai Siklus II Siswa

\begin{tabular}{|c|c|c|c|c|}
\hline \multirow{2}{*}{ No } & \multirow{2}{*}{ Nama Siswa } & \multirow{2}{*}{ Siklus II } & \multicolumn{2}{|c|}{ Keterangan } \\
\hline & & & Tuntas & Belum Tuntas \\
\hline 1 & Abdullah & 85 & Ö & \\
\hline 2 & Anis & 65 & & Ö \\
\hline 3 & Agung & 75 & Ö & \\
\hline 4 & Ahmad & 85 & Oे & \\
\hline 5 & Ahyar & 85 & Ö & \\
\hline 6 & $\mathrm{Aji}$ & 80 & Oे & \\
\hline 7 & Amelia & 85 & Oे & \\
\hline 8 & Ani & 80 & Ö & \\
\hline 9 & Annisa & 80 & Oे & \\
\hline 10 & Azil & 70 & Ö & \\
\hline 11 & Chelsea & 65 & & $\ddot{O}$ \\
\hline 12 & Dhe & 80 & Oे & \\
\hline 13 & Diva & 75 & Ô & \\
\hline 14 & Duta & 85 & Ö & \\
\hline 15 & Endi & 80 & Ö & \\
\hline 16 & Eva & 75 & Ö & \\
\hline 17 & Fahsa & 65 & & Ö \\
\hline 18 & Febrian & 85 & Ö & \\
\hline 19 & Hadi & 85 & Ö & \\
\hline 20 & Hanif & 85 & Ö & \\
\hline
\end{tabular}




\begin{tabular}{|c|c|c|c|c|}
\hline 21 & Iqbal & 75 & Ö & \\
\hline 22 & Ira & 80 & Ö & \\
\hline 23 & Kiki & 75 & Ö & \\
\hline 24 & Lilis & 75 & Ö & \\
\hline 25 & Lela & 80 & Ö & \\
\hline 26 & Meiza & 85 & Ö & \\
\hline 27 & Meta & 75 & Ö & \\
\hline 28 & Milfi & 80 & Ö & \\
\hline 29 & Tatia & 90 & Ö & \\
\hline 30 & Taza & 85 & Ö & \\
\hline 31 & Tedi & 75 & Ö & \\
\hline 32 & Vero & 80 & Ö & \\
\hline 33 & Yoga & 85 & Ö & \\
\hline 34 & Pebri & 90 & Ö & \\
\hline \multicolumn{2}{|c|}{ Jumlah } & 2700 & 31 & 3 \\
\hline \multirow{2}{*}{\multicolumn{2}{|c|}{$\begin{array}{l}\text { Rata-rata } \\
\% \text { ketuntasan } \geq 70\end{array}$}} & 79.41 & & \\
\hline & & & 91.18 & 8.82 \\
\hline \multirow{2}{*}{\multicolumn{2}{|c|}{ Nilai }} & Tertinggi & 90 & \\
\hline & & Terendah & 65 & \\
\hline
\end{tabular}

Dari tabel 3 di atas diperoleh data bahwa jumlah anak yang tuntas sebanyak 31 siswa atau sebesar $91,18 \%$ sedangkan yang belum tuntas sebanyak 3 siswa atau $8,82 \%$. Nilai rata-rata yang diperoleh siswa sebesar 79,41 dengan nilai tertinggi sebesar 90 dan nilai terendah sebesar 65 . Jika dilihat dari ketuntasan belajar, terlihat bahwa siklus II tuntas. Hal ini dikarenakan ketuntasan siswa telah melebihi ketuntasan siswa secara klasikal 91,18\%. Dari uraian diatas dapat digabungkan hasil evaluasi persiklus seperti pada tabel berikut :

Tabel 4

Hasil Belajar Siswa

\begin{tabular}{lllll}
\hline \multirow{2}{*}{ No. } & \multirow{2}{*}{ Nama } & Nilai & & \\
\cline { 3 - 5 } & & Pra Siklus & Siklus I & Siklus II \\
\hline 1 & Abdullah & 60 & 70 & 85 \\
\hline 2 & Anis & 45 & 60 & 65 \\
\hline 3 & Agung & 55 & 60 & 75 \\
\hline 4 & Ahmad & 60 & 75 & 85 \\
\hline 5 & Ahyar & 75 & 80 & 85 \\
\hline 6 & Aji & 70 & 75 & 80 \\
\hline 7 & Amelia & 75 & 80 & 85 \\
\hline 8 & Ani & 60 & 75 & 80 \\
\hline 9 & Annisa & 45 & 75 & 80 \\
\hline 10 & Azil & 55 & 65 & 70 \\
\hline 11 & Chelsea & 65 & 60 & 65 \\
\hline
\end{tabular}




\begin{tabular}{llllll}
\hline 12 & Dhe & 55 & 75 & 80 \\
\hline 13 & Diva & 70 & 70 & 75 \\
\hline 14 & Duta & 70 & 70 & 85 \\
\hline 15 & Endi & 65 & 65 & 80 \\
\hline 16 & Eva & 70 & 75 & 75 \\
\hline 17 & Fahsa & 75 & 70 & 65 \\
\hline 18 & Febrian & 70 & 80 & 85 \\
\hline 19 & Hadi & 65 & 80 & 85 \\
\hline 20 & Hanif & 60 & 75 & 85 \\
\hline 21 & Iqbal & 45 & 70 & 75 \\
\hline 22 & Ira & 45 & 70 & 80 \\
\hline 23 & Kiki & 55 & 65 & 75 \\
\hline 24 & Lilis & 60 & 65 & 75 \\
\hline 25 & Lela & 55 & 70 & 80 \\
\hline 26 & Meiza & 60 & 75 & 85 \\
\hline 27 & Meta & 65 & 65 & 75 \\
\hline 28 & Milfi & 65 & 65 & 80 \\
\hline 29 & Tatia & 70 & 65 & 90 \\
\hline 30 & Taza & 70 & 70 & 85 \\
\hline 31 & Tedi & 65 & 75 & 75 \\
\hline 32 & Vero & 55 & 75 & 80 \\
\hline 33 & Yoga & 45 & 75 & 85 \\
\hline 34 & Pebri & 60 & 80 & 90 \\
\hline Jumlah & & 2080 & 2420 & 2700 \\
\hline Rata-rata & 61.18 & 71.18 & 79.41 \\
\hline$\%$ ketuntasan $\geq 70$ & $29.41 \%$ & $67.65 \%$ & $91.18 \%$ \\
\hline & & & 65 \\
\hline
\end{tabular}

Berdasarkan tabel 4 terlihat bahwa hasil belajar siswa dalam pembelajaran PAI materi zakat menunjukkan peningkatan dari satu siklus ke siklus berikutnya. Keadaan sebelum perbaikan pembelajaran, jumlah siswa yang mencapai ketuntasan belajar atau memperoleh nilai $\geq 70$ baru mencapai 10 orang $(29.41 \%$ ), pada siklus I yang mencapai ketuntasan belajar 23 orang (67.61\%) dan pada siklus II tingkat ketuntasan mencapai 31 orang $(91.18 \%)$. Maka pelaksanaan pembelajaran PAI ini sudah dapat dikatakan berhasil karena sudah memenuhi syarat ketuntasan minimal klasikal yaitu $85 \%$ siswa yang mencapai nilai $\geq 70$. 


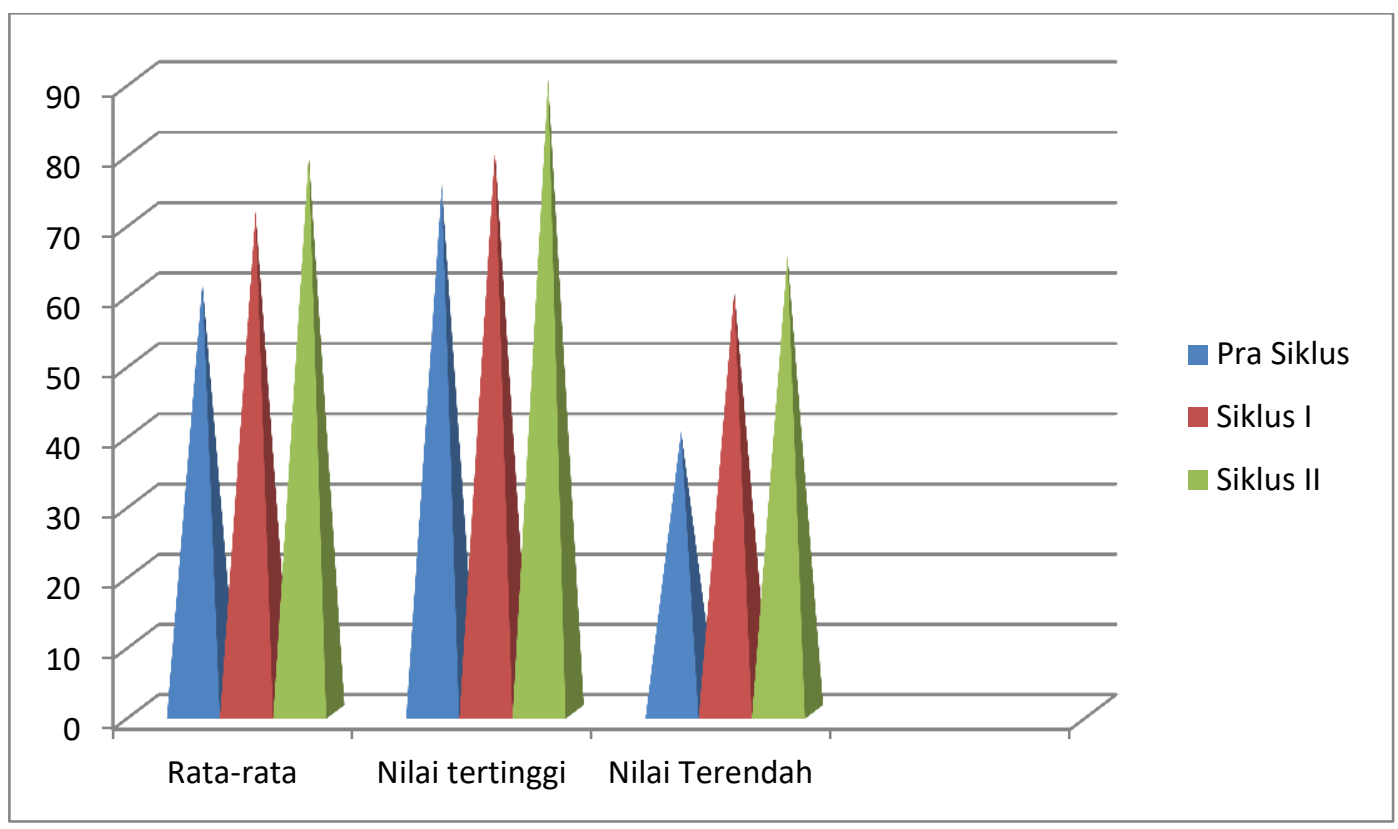

Gambar 1 Hasil Penelitian Persiklus

\section{PEMBAHASAN}

\section{Minat Siswa}

Minat siswa yang dimaksud dalam penelitian ini terbagi menjadi tiga yaitu terlibat aktif (tinggi), artinya siswa menyimak dengan sungguh-sungguh, mengajukan pertanyaan, mampu menjawab pertanyaan dengan benar, ikut aktif berdiskusi dan berani mengeluarkan pendapat. Terlibat pasif (sedang), artinya siswa menyimak dengan sungguh-sungguh, menjawab pertanyaan tetapi belum tentu benar dan ikut berdiskusi. Tidak terlibat (rendah), artinya siswa tidak mau bertanya, tidak menjawab dan diam saja.

Pada saat pratindakan minat belajar siswa rendah dimana sebanyak 9 siswa (26.47\%) terlibat aktif. Siswa yang terlibat tidak aktif sebesar 16 siswa (47.06\%). Setelah perbaikan pembelajaran siklus I telah terjadi peningkatan jumlah siswa yang terlibat aktif sebanyak 15 siswa $(44.12 \%)$ dengan penurunan jumlah siswa yang tidak terlibat aktif yaitu 9 orang $(26.47 \%)$. Sedangkan dari siklus I ke siklus II siswa yang aktif tinggi meningkat menjadi 29 (85.29\%) dan siswa yang tidak terlibat aktif sebanyak 1 orang $(2,94 \%)$.

\section{Prasiklus (Sebelum Tindakan Perbaikan)}

Prasiklus dilaksanakan pada Rabu, 4 april 2018. Prasiklus dilakukan untuk melihat keaktifan dan hasil belajar siswa. Hasil prasiklus jumlah anak yang tuntas sebanyak 10 siswa atau sebesar 29,41\% sedangkan yang belum tuntas sebanyak 24 siswa atau 70,59\%. Nilai rata-rata yang diperoleh siswa sebesar 61,18 dengan nilai 
tertinggi sebesar 75 dan nilai terendah sebesar 40. Jika dilihat dari ketuntasan belajar, terlihat bahwa pada saat pra siklus ini masih belum tuntas. Hal ini dikarenakan ketuntasan siswa hanya sebesar $23,53 \%$. Sedangkan ketuntasan siswa secara klasikal harus sebesar $85 \%$.

\section{Siklus I}

Pelaksanaan siklus I yang dilaksanakan pada hari Rabu, 11 April 2018. Pada pembelajaran siklus I dilakukan upaya perbaikan dengan menggunakan model pembelajaran Think Talk Write. Jumlah anak yang tuntas sebanyak 23 siswa atau sebesar $67,65 \%$ sedangkan yang belum tuntas sebanyak 11 siswa atau 32,35\%. Nilai rata-rata yang diperoleh siswa sebesar 71,18 dengan nilai tertinggi sebesar 80 dan nilai terendah sebesar 60. Jika dilihat dari ketuntasan belajar, terlihat bahwa pada saat siklus I ini masih belum tuntas. Hal ini dikarenakan ketuntasan siswa hanya sebesar $67,65 \%$. Sedangkan ketuntasan siswa secara klasikal harus sebesar $85 \%$.

\section{Siklus II}

Pelaksanaan siklus II yang dilaksanakan pada hari Rabu, 18 April 2018. Pada pembelajaran siklus II dilakukan upaya perbaikan dengan menggunakan model pembelajaran Think Talk Write. Jumlah anak yang tuntas pada siklus II sebanyak 31 siswa atau sebesar 91,18\% sedangkan yang belum tuntas sebanyak 3 siswa atau $8,82 \%$. Nilai rata-rata yang diperoleh siswa sebesar 79,41 dengan nilai tertinggi sebesar 90 dan nilai terendah sebesar 65. Jika dilihat dari ketuntasan belajar, terlihat bahwa siklus II tuntas. Hal ini dikarenakan ketuntasan siswa telah melebihi ketuntasan siswa secara klasikal 91,18\%.

\section{SIMPULAN}

Berdasarkan uraian yang telah disampaikan pada pelaksanaan Penelitian Tindakan Kelas di Kelas III SD Negeri 4 Lubuklinggau dapat disimpulkan bahwa penerapan model pembelajaran Think Talk Write dapat meningkatkan hasil belajar siswa kelas VI SD Negeri 49 Lubuklinggau Pada Materi Zakat. Keadaan sebelum perbaikan pembelajaran, jumlah siswa yang mencapai ketuntasan belajar atau memperoleh nilai $\geq 70$ baru mencapai 10 orang $(29.41 \%)$, pada siklus I yang mencapai ketuntasan belajar 23 orang $(67.61 \%)$ dan pada siklus II tingkat ketuntasan mencapai 31 orang $(91.18 \%)$. Maka pelaksanaan pembelajaran Matematika ini sudah dapat dikatakan berhasil karena sudah memenuhi syarat ketuntasan minimal klasikal yaitu $85 \%$ siswa yang mencapai nilai $\geq 70$ 


\section{DAFTAR PUSTAKA}

Anitah, S. (2008). Strategi Pembelajaran di SD, Jakarta: Universitas Terbuka

Wardhani, I.G.A.K,. (2007). Penelitian Tindakan Kelas (PTK), Jakarta: Universitas Terbuka.

Maidar, G. A \& Mukti. (2010). Metode Pembelajaran. Jakarta: Gramedia

Nadir. (2009). Pendidikan Agama Islam. Surabaya: Amanah Pustaka.

Sapriya, (2008). Pendidikan PAI. Bandung: Laboratorium PKn UPI Press. 